\title{
The influence of oral cimetidine administration on creatinine clearance in chilren with chronic renal failure: A preliminary study
}

\author{
Rosalina D Roeslani, MD; Partini P Trihono, MD, MM(Paed); Sri Rezeki Harun, MD, PhD
}

\begin{abstract}
Background Serum creatinine and creatinine clearance are used to assess glomerular filtration rate but have a major disadvantage since a variable amount of creatinine is secreted in the proximal tubule. This may cause an unpredictable overestimation of GFR. Tubular creatinine secretion can be blocked by cimetidine through competitive inhibition of cation transport in the proximal tubular luminal membrane.

Objective Cimetidine administration might improve the reliability of creatinine as a marker of glomerular filtration.

Methods A preliminary study with a one-group pretest-posttest design in 11 children with chronic renal failure. Serum cystatin C level as reference value was compared with creatinine clearance measured before and after oral ingestion of cimetidine. The dose of cimetidine was adjusted with the GFR using Schwartz formula. Statistical evaluation was done with the Wilcoxon signed ranks test.

Result The mean creatinine clearance before cimetidine administration was 27.4 (SD 14.6) $\mathrm{ml} /$ minute $/ 1.73 \mathrm{~m}^{2} \mathrm{BSA}$, and decreased after cimetidine to $21.1(\mathrm{SD} 13,1) \mathrm{ml} / \mathrm{minute} / 1.73 \mathrm{~m}^{2} \mathrm{BSA}(\mathrm{p}=0.015)$. Conclusion Oral cimetidine was effective in inhibiting creatinine tubular secretion. This study could not prove that cimetidine improves the accuracy of creatinine clearance [Paediatr Indones 2005;45:14-17].
\end{abstract}

Keywords: chronic renal failure, creatinine clearance, cimetidine, cystatin $\mathrm{C}$

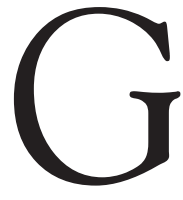
lomerular filtration rate is the accepted parameter for monitoring renal function in urinary tract and kidney disorders., ${ }^{1,2}$ The known gold standard for measuring GFR is inulin clearance $\left(\mathrm{C}_{\mathrm{In}}\right)$. In clinical practice, GFR is monitored by using plasma creatinine concentrations or creatinine clearance $\left(\mathrm{C}_{\mathrm{cr}}\right)$, although numerous studies have documented the inaccuracy of these estimates. ${ }^{1}$ The discrepancy is primarily a result of tubular secretion of creatinine. . $^{3-7}$ The disparity between $\mathrm{C}_{\mathrm{cr}}$ and $\mathrm{C}_{\mathrm{In}}$ increases as GFR decreases because of the increasing creatinine secretion at the tubular part when GFR deteriorates. ${ }^{1}$ $\mathrm{C}_{\mathrm{cr}}$ closely approximates GFR when tubular secretion of creatinine is inhibited by cimetidine $e^{1,2-7}$ through competitive inhibition of the cation transport in the proximal tubular luminal membrane. ${ }^{3}$ For our study we used serum cystatin $\mathrm{C}$ level as the standard value for GFR since it is more accurate than creatinine clearance and correlates well with inulin clearance as the gold standard of GFR. ${ }^{8,9}$

The aim of the present study was to determine whether oral administration of cimetidine would improve the accuracy of creatinine clearance with reference to serum cystatin $\mathrm{C}$ level in children with chronic renal failure (CRF).

From the Department of Child Health, Medical School, University of Indonesia, Cipto Mangunkusumo Hospital, Jakarta, Indonesia.

Reprint requests to: Rosalina D Roeslani, MD, Department of Child Health, Medical School, University of Indonesia, Cipto Mangunkusumo Hospital, Jakarta, Indonesia. Tel. 62-21-3907740, Fax. 62-21-3907743. 
Rosalina D Roeslani et al: The influence of cimetidine on creatinine clearance in chilren with chronic renal failure

\section{Methods}

This study was conducted from April to September 2003, using a one group pretest-posttest design in the Paediatric Kidney Center at Cipto Mangunkusumo Hospital, University of Indonesia. Prior to this study the sample size was determined using a two pair formula with $80 \%$ power of study and a significant difference of 0.05. The sample size was 35 patients, collected by consecutive sampling. Subjects were eligible for the study if they had GFR below $30 \mathrm{ml} /$ minute $/ 1.73 \mathrm{~m}^{2}$ body surface area (BSA) for at least 3 months, were between 6-18 years of age (to avoid difficulties in collecting urine sample), did not take regular cimetidine, trimethoprim, or salicylates, and their parents gave informed consent. Subjects were excluded if they could not finish this study. This study was approved by the Committee of the Medical Research Ethics of the Faculty of Medicine, University of Indonesia.

For the first sampling, the children were asked to bring a 24-hour urine collection (completed 12 hours previously). A blood sample was obtained to determine plasma creatinine and cystatin $\mathrm{C}$ concentration. Serum and urine creatinine concentrations were measured using the Jaffe rate method and serum cystatin $\mathrm{C}$ level determined by particle-enhanced nephelometric immunoassay using the Behring cystatin C level determination kit. These assays were examined at the Department of Clinical Pathology, Cipto Mangunkusumo Hospital.

The dose of oral cimetidine was calculated according to plasma creatinine using the Schwartz formula and adjusted with a modification of the regimen described by Hillbrands, et al. Patients with a $\mathrm{C}_{\mathrm{cr}}>75 \mathrm{ml} / \mathrm{minute} / 1.73 \mathrm{~m}^{2} \mathrm{BSA}$ received $20 \mathrm{mg} / \mathrm{kg} /$ dose of cimetidine to a maximum of 1,600 $\mathrm{mg}$. The dose was reduced to $8 \mathrm{mg} / \mathrm{kg}$ for patients with $\mathrm{C}_{\mathrm{cr}}$ of $50-75 \mathrm{ml} / \mathrm{minute} / 1.73 \mathrm{~m}^{2} \mathrm{BSA}$, and to $7 \mathrm{mg} / \mathrm{kg}$ for $\mathrm{C}_{\mathrm{cr}}$ of $30-50 \mathrm{ml} / \mathrm{minute} / 1.73 \mathrm{~m}^{2} \mathrm{BSA}$ to $6 \mathrm{mg} / \mathrm{kg} /$ dose for a $\mathrm{C}_{\mathrm{cr}}$ of $20-30 \mathrm{ml} / \mathrm{minute} / 1.73 \mathrm{~m}^{2} \mathrm{BSA}$, and to $5 \mathrm{mg} / \mathrm{kg} / \mathrm{dose}$ for a $\mathrm{C}_{\mathrm{cr}}$ of $<20 \mathrm{ml} /$ minute $/ 1.73 \mathrm{~m}^{2}$ BSA. Cimetidine was administered at roughly 12 hour intervals up to a total of five doses.

Twelve hours after administration of the fifth dose of cimetidine, the children came for the second visit. The children were asked to bring a 24-hour urine collection obtained earlier (the second urine collection started after the third dose of cimetidine was adminis- tered. Twelve hours proceeding urine collection until the 24-hour urine collection was completed, the children were instructed not to eat meat, fish, and fowl (i.e., free of preformed creatinine and creatinine precursors). A second blood sample was drawn for plasma creatinine and creatinine clearance examination.

The parents were asked to supervise urine collection at home, making sure that the children emptied their urinary bladders completely for a period of roughly 24 hours; all urine voided was to be collected in the container provided. On the morning of the visit, the exact time of the final void was recorded. If one or more void was not collected, they were asked to start again from the beginning. We supervised the urine collection by phone or mail or visited the patient at home. The study was performed during school holidays; otherwise we asked teachers' permission for the children to miss school during this study.

Data were expressed as mean \pm standard deviation (SD). The paired t-test was used to recognize the change of creatinine clearance test before and after oral administration of cimetidine. If the coefficient of variation was more than $20 \%$, the Wilcoxon signed ranks test would be used.

\section{Results}

\section{Patient characteristics}

Only 11 patients participated for this preliminary study, 8 males and 3 females. At the beginning of the study, 6 patients were between $10-14$ years old, 4 were between 6-9 years old, and only 1 was between $15-18$ years old. The youngest patient was 6 years old and the oldest 16 years, the mean age was 11 years $(\mathrm{SD}=3.3)$. Primary causes of chronic renal failure were obstructive uropathy (2 patients with neurogenic bladder and 2 with renal agenesis), nephrotic syndrome (2 patients), CRF caused by chemotherapy for retinoblastoma, chronic pyelonephritis (1 patient), lupus nephritis (1 patient), and rapid progressive glomerulonephritis (1 patient).

\section{Renal function test}

Table 2 shows the mean cystatin $\mathrm{C}$ and creatinine clearance before and after oral cimetidine administration. 
Tabel 1. Primary cause of chronic renal failure (CRF)

\begin{tabular}{ll}
\hline Primary renal disease & N \\
\hline - Anatomical abnormality & \\
$\quad$ - Neurogenic bladder & 2 \\
$\quad$ - Renal agenesis & 2 \\
- Retinoblastoma & 2 \\
- Nephrotic syndrome & 2 \\
- Chronic pyelonephritis & 1 \\
- Lupus nephritis & 1 \\
- Progressive glomerulonephritis & 1 \\
\hline Total & $\mathbf{1 1}$ \\
\hline
\end{tabular}

The mean creatinine clearance after ingesting cimetidine was 21.1 (SD 13.1) $\mathrm{ml} /$ minute $/ 1.73 \mathrm{~m}^{2} \mathrm{BSA}$, which was lower than before cimetidine ( 27.4 (SD 14.6) $\mathrm{ml} /$ minute $/ 1.73 \mathrm{~m}^{2} \mathrm{BSA}$ ) and the difference was significant $(\mathrm{P}=0.015)$.

\section{Discussion}

The power of this study was reduced from $80 \%$ to $65.5 \%$ because of the small number of subjects, i.e., eleven patients. We chose serum cystatin $\mathrm{C}$ level as reference value for GFR in this study because of the simple test procedure and because cystatin C concentration is independent of the patient's age (over 2 years of age), sex, intake, and body height. ${ }^{8-14}$ Ylinen et al. demonstrated that GFR measured by serum cystatin $C$ level had good correlation with ${ }^{51} \mathrm{CR}$ EDTA $(\mathrm{r}=0.84){ }^{8}$

Table 2 shows that the creatinine clearance value after oral cimetidine tends to be lower than creatinine clearance pre-cimetidine $(\mathrm{P}<0.05)$. This proved that oral administration of cimetidine could inhibit tubular creatinine secretion. The same result by Kemperman et al. ${ }^{4}$ found that creatinine clearance after oral cimetidine was 86 (SD 34) $\mathrm{ml} /$ minute $/ 1.73 \mathrm{~m}^{2} \mathrm{BSA}$, which is lower compared to clearance before cimetidine,

Table 2. Mean of Cystatin C Concentration and CREatinin CLEARANCE BEFORE AND AFTER ORAL ADMINISTRATION OF CIMETIDINE

\begin{tabular}{lllll}
\hline Renal function test & $\mathbf{N}$ & Mean & SD & CV (\%) \\
\hline Cystatin C & 11 & $3.6^{*}$ & 2.3 & 63.9 \\
$\mathrm{C}_{\mathrm{cr}}$ before cimetidine & 11 & $27.4^{+}$ & 14.6 & 53.6 \\
$\mathrm{C}_{\mathrm{cr}}$ after cimetidine & 11 & $21.1^{+}$ & 13.1 & 61.9 \\
\hline $\mathrm{C}_{\mathrm{cr}}=$ Creatinine clearance, & ${ }^{*}=\mathrm{mg} / \mathrm{l},{ }^{+}=\mathrm{ml} / \mathrm{minute} / 1.73 \mathrm{~m}^{2} \mathrm{BSA}$, \\
$\mathrm{CV}=$ coeffecient of variation. \\
Wilcoxon signed rank test showed significant difference in creatinine \\
clearance before and after cimetidine ( $\mathrm{p}$ 0.015 ).
\end{tabular}

which was 102 (SD 40) $\mathrm{ml} /$ minute $/ 1.73 \mathrm{~m}^{2}$ BSA $(\mathrm{P}<0.05)$.

To simplify the analysis, several studies designed formulas to estimate GFR via serum cystatin $\mathrm{C}$ such as those done by Bökenkamp and Arnal. ${ }^{9,10}$ At present, there is no formula yet to be considered the most reliable for GFR estimation via serum cystatin C. The Bökenkamp formula was derived from 56 children with impaired renal function and inulin clearance as a gold standard, as follows: ${ }^{9}$

GFR $\left(\mathrm{ml} /\right.$ minute $\left./ 1.73 \mathrm{~m}^{2} \mathrm{BSA}\right)=137 /$ cystatin C $(\mathrm{mg} / \mathrm{l})-20,4$

Meanwhile, the Arnal formula was introduced at the Cystatin C expert meeting in Marburg on April 2002, as follows: ${ }^{10}$

\section{$\operatorname{GFR}\left(\mathrm{ml} /\right.$ minute $\left./ 1.73 \mathrm{~m}^{2}\right)=$}

$$
\begin{aligned}
& 74.83 \\
& \text { Cystatin C } 1 / 0,75 \quad \text { Body surface area }\left(\mathrm{m}^{2}\right)
\end{aligned}
$$

Table 3 shows the comparison between the mean GFR estimation by Bökenkamp and Arnal formulas (both evaluated via values of cystatin C), compared to creatinine clearance before and after cimetidine in our present study.

Only eight subjects were able to be estimated for GFR values via serum cystatin C by Bökenkamp formula since the other 3 had cystatin C over $6 \mathrm{mg} / \mathrm{l}$ and gave a negative result. This situation might be because Bökenkamp had subjects who were not in the terminal state of CRF. The difference of GFR values calculated by cystatin C compared to creatinine clearance before administration of cimetidine was $11 \mathrm{ml} /$ minute $/ 1.73 \mathrm{~m}^{2} \mathrm{BSA}$, while the difference after ingesting cimetidine was $15.9 \mathrm{ml} /$ minute $/ 1.73 \mathrm{~m}^{2} \mathrm{BSA}$. This result shows that creatinine clearance after oral administration of cimetidine did not closely approximate to cystatin $\mathrm{C}$ as reference value.

Similar results were found when the calculation was done by Arnal formula in all 11 patients. Mean GFR estimate via cystatin $\mathrm{C}$ was $34.5(\mathrm{SD}=23.8) \mathrm{ml} /$ minute $/ 1.73 \mathrm{~m}^{2} \mathrm{BSA}$. The mean difference compared to creatinine clearance before cimetidine was $7.1 \mathrm{ml} /$ minute $/ 1.73 \mathrm{~m}^{2} \mathrm{BSA}$ while the difference compared to 
Rosalina D Roeslani et al: The influence of cimetidine on creatinine clearance in chilren with chronic renal failure

Tabel 3. Creatinine clearance before and after oral administration of Cimetidine compared to GFR estimation Via Cystatin $C$ by Bökenkamp and Arnal formula

\begin{tabular}{lllll}
\hline Renal function test & \multicolumn{2}{l}{$\begin{array}{l}\text { Bökenkamp Formula } \\
\mathbf{n}\end{array}$} & Mean (SD) & \multicolumn{2}{l}{$\begin{array}{c}\text { Arnal Formula } \\
\text { Nean (SD) }\end{array}$} \\
\hline Cystatin C & 8 & $43.50($ SD 21.41) & 11 & $34.50($ SD 23.80) \\
Ccr before cimetidine & 8 & $32.50($ SD 11.60) & 11 & 27.40 (SD 14.60) \\
Ccr after cimetidine & 8 & $27.60($ SD 8.10) & 11 & 21.10 (SD 13.10) \\
\hline
\end{tabular}

$\mathrm{C}_{\mathrm{Cr}}$ : creatinin clearance ${ }^{*}: \mathrm{ml} /$ minute/1.73 $\mathrm{m}^{2} \mathrm{BSA}$

creatinine clearance after cimetidine was $13.4 \mathrm{ml} /$ minute $/ 1.73 \mathrm{~m}^{2} \mathrm{BSA}$. The larger value of creatinine clearance after cimetidine means a failure of this study which might be caused by the small sample size or the possibility that the Bökenkamp and Arnal formulae are inappropriate for this study.

Stoves et al. found that Bökenkamp formula overestimated GFR measured by ${ }^{99 \mathrm{~m}} \mathrm{Tc}$ DTPA with a bias value of $11.1 \mathrm{ml} /$ minute $/ 1.73 \mathrm{~m}^{2} .{ }^{11}$ By contrast with our finding, Serdar et al. ${ }^{7}$ and Hellerstein et al. ${ }^{1}$ found that oral administration of cimetidine improved the accuracy of creatinine clearance.

In conclusion, oral administration of cimetidine could inhibit tubular secretion of creatinine, but our study failed to show improved accuracy of creatinine clearance. A multicenter study involving children with various degrees of CRF might be necessary to ascertain the role of cimetidine in improving the accuracy of creatinine clearance.

\section{References}

1. Hellerstein S, Berenbom M, Alon US, Warady BA. Creatinine clearence following cimetidine for estimation of glomerular filtration rate. Pediatr Nephrol 1998;12:49-54.

2. Levey A. Clinical evaluation of renal function. In: Greenberg A, Cheung AK, Falk RJ, Coffman TM, Jennete JC, eds. Primer on Kidney diseases. San Diego: Academic Press Limited; 1994. p. 17-23.

3. Hilbrands LB, Artz MA, Wetzels JFM, Koene RAP. Cimetidine improves the realiability of creatinine as a marker of glomerular filtration. Kidney Int 1991;40:1171-6.

4. Kemperman FAV, Silberbusch J, Slaats EH, Prins AM, Weber JA, Krediet RT, et al. Estimation of glomerular filtration rate in NIDDM patients from plasma creatinin concentration after cimetidine administration. Diabetes Care 1998; 21: 216-20.
5. Zaltzman J, Whiteside C, Cattran DC, Lopez FM, Logan AG. Accurate measurement of impaired glomerular filtration using single-dose oral cimetidine. Am J Kidney Dis 1996; 27:504-11.

6. Van Acker BAC, Koomen GCM, Koopman MG, De Waart DR, Arisz L. Creatinine clearance during cimetidine administration for measurement of glomerular filtration rate. Lancet 1992; 340:1326-9.

7. Serdar MA, Kurtz I, Urhan M, Ilgan S, Yenicesu M, Kenar L, et al. A practical approach to glomerular filtration rate measurements: creatinine clearance estimation using cimetidine. Ann Clin Lab Sci 2001; 31:265-73.

8. Ylinen EA, Hauhala MA, Harmoinem APT, Knip M. Cystatin-C as a marker for glomerular filtration rate in pediatric patients. Pediatr Nephrol 1999; 13:506-9.

9. Bökenkamp A, Domanetzki M, Zinck R, Schumann G, Byrd D, Brodehl J. Cystatin C serum concentrations underestimate glomerular filtration rate in renal transplant recipients. Clin Chem 1999;45:1866-8.

10. Bricon TL. Cystatin C in renal transplantation. Presented at International Expert Meeting on Cystatin C and GFR Assessment, Marburg; 2002 April 15-16; Marburg, Germany.

11. Stoves J, Bosomworth M, Newstead CG. Cystatin C as aguide to glomerular filtration rate in renal transplant recipients with chronic allograft nephropathy. Clin Chem 2002; 32:1467.

12. Bokenkamp A, Damonetzki M, Zinck R, Schumann G, Brodehl J. Reference values for cystatin-C serum concentrations in children. Pediatr Nephrol 1998; 12:125-9.

13. Filler G, Priem F, Vollmer I, Gellermann J, Jung K. Diagnostic sensitivity of serum cystatin for impaired glomerular filtration rate. Pediatr Nephrol 1999; 13:501-5.

14. Harmoinen A, Ylinen E, Houhala MA, Janas M, Kaila $\mathrm{M}$, Kouri T. Reference intervals for cystatin-C in preand full-term infants and children. Pediatr Nephrol 2000;15:105-8. 